\title{
Bailout or bust? Government evaluations in the wake of a bailout
}

\author{
Erik Gahner Larsen ${ }^{1 \star} \mathbb{D}$, Robert Klemmensen ${ }^{2}$ and Michael Baggesen Klitgaard ${ }^{2}$ \\ ${ }^{1}$ School of Politics and International Relations, University of Kent, Canterbury, United Kingdom and ${ }^{2}$ Department of Political \\ Science, University of Southern Denmark, Odense, Denmark \\ ${ }^{\star}$ E-mail: E.G.Larsen@kent.ac.uk
}

(Received 07 June 2018; revised 21 March 2019; accepted 30 March 2019)

\begin{abstract}
Governments are often punished for negative events such as economic downturns and financial shocks. However, governments can address such shocks with salient policy responses that might mitigate public punishment. We use three high-quality nationally representative surveys collected around a key event in the history of the Dutch economy, namely the outbreak of the financial crisis in 2008 , to examine how voters responded to a salient government bailout. The results illustrate that governments can get substantial credit for pursuing a bailout in the midst of a financial crisis. Future research should take salient policy responses into account to fully understand the public response to the outbreak of financial and economic crises.
\end{abstract}

Keywords: financial crisis; bailout; democratic accountability; government behavior; public opinion

\section{Introduction}

The global financial and economic crisis in 2007-09 was the worst of its kind since the Great Depression of the 1930s. The outbreak of the crisis once again catapulted the economy to the apex of the political agenda and forced democratic governments in rich nations to follow austerity policies. Governments in most Western countries enacted comprehensive plans for economic recovery, cut back on the generosity of public service, and bailed out ailing financial institutions.

Decades of research show that economy is important for voters' assessment of the government (Fiorina 1978; Nannestad and Paldam 1994; van der Brug et al. 2007; Dassonneville and LewisBeck 2019), and a growing body of research has examined the relevance of the economy for government support in the wake of the financial and economic crisis (Malhotra and Margalit 2010; Anderson and Hecht 2012; Lindvall 2014; Bisgaard 2015; Teixeira et al. 2016; Margalit 2019). In this article, we contribute to this growing body of literature and observe how the public responds to a salient government bailout. Specifically, we analyze whether voters unconditionally punish the government for a financial crisis. Interestingly, recent research suggests that voters are retrospective and might not disentangle the nature of a financial crisis from actual government behavior.

This proves to be an important puzzle as we know that governments can be popular in times of economic distress. Duch and Stevenson (2008), for example, demonstrate that there is substantial variation in the size of the economic vote. The question is whether a salient government bailout will result in worse government evaluations due to the financial crisis it is addressing or pave way for better government evaluations due to the policy response. Though it might be true that voters are blind in their retrospections, it might as well be the case that they do not evaluate the government more negatively as a result of a negative event such as a financial crisis.

To address methodological challenges in estimating the impact of government bailouts, we narrow in on a key event in the history of the Dutch economy to provide evidence from three data 
sources on how the public reacted to the outbreak of the financial crisis in 2008 (Fassin and Gosselin 2011). On September 26, 2008, the bank Dutch Fortis unexpectedly lost approximately $21 \%$ of its value on the Amsterdam Stock Exchange as the financial systems careened toward the abyss: 20 billion euros were withdrawn and a further 30 billion euros were expected to be withdrawn on September 29. The Dutch government responded with a salient bailout on September 28 when Fortis was partially nationalized.

For our analysis, we relied on three high-quality nationally representative surveys. The first survey is a cross-sectional survey from the European Social Survey (ESS), which was in the field during the crisis. The second survey is a panel dataset from the Longitudinal Internet Studies for the Social Sciences (LISS) collected in December 2007 and a few months after the outbreak of the crisis. The third survey is a repeated cross-sectional sample from the Eurobarometer conducted before and after the outbreak of the crisis. The findings from all surveys indicate that the government was not punished for the financial crisis. On the contrary, the estimates suggest that the government gained support. We also analyzed whether this response was heterogeneous in the public, that is, conditional upon partisanship and socioeconomic characteristics. Although we find partial support for a heterogeneous response, this is not in line with a biased reaction in a partisan manner.

In sum, voters are not unconditionally blind in their retrospective evaluations. On the contrary, how governments respond to specific economic and financial events have significant implications for how the public assesses their performance. Consequently, and as advocates of democratic accountability might welcome, governments have opportunities to alleviate the consequences of financial crises.

\section{Credit, blame and retrospective evaluations}

Previous research suggests that voters might punish governments in the wake of economic downturns. Voters are retrospective but do not necessarily disentangle the state of the economy from actual government behavior. Achen and Bartels (2016) summed up this account of retrospective assessments: 'Our assertion is that voters' retrospections are blind, not just in natural disasters but in hardships of all kinds' (118). This suggests that voters can rely on the economy as an important heuristic when assessing the quality of the government, paying little to no attention to the policies governments pursue. However, Achen and Bartels (2016) propose an alternative argument as well: 'An alternative defense of voter rationality is that the electorate punishes incumbents not for the occurrence of natural disasters, which are clearly beyond their control, but for insufficient responses to those disasters' (136, italics in original). Consequently, they open the door for policy actions taken by governments to be important mediators of government approval in times of economic crises. As we will argue in the sections that follow, a government bailout is a suitable case to test this, as we have not only the occurrence of an economic downturn, but also a salient and direct response to such a crisis.

There is widespread consensus that voters hold governments responsible for macroeconomic outcomes (for reviews, see Lewis-Beck and Stegmaier 2000; 2007). In brief, voters rely on economic information when evaluating government competence which enables them to retrospectively evaluate and hold the government accountable (Healy and Malhotra 2013). Hence, the public follows in most cases the competence and performance of the government in the economic domain. There are two different ways in which voters can look at the economic issue with implications for how they might react to a government bailout, namely the economy as a valence issue or a positional issue (Lewis-Beck and Nadeau 2011). If voters respond only to the negative valence of the economy, then government evaluations should suffer from the outbreak of a financial crisis. However, if voters are attentive to the economy as a policy position issue, then government evaluations should be more positive in the wake of a popular and salient policy response to a crisis.

There is convincing evidence that voters do not unconditionally punish the government for a bad economy. Interestingly, though studies rely on various explanations for how voters process 
the economy, they bring the same conclusion on attribution of responsibility to the table: governments are able to disclaim the responsibility for economic downturns such as financial shocks and hence mitigate public punishment for an adverse economy. However, only limited attention has been devoted to substantiate how governments might not only mitigate punishment for economic downturns but also gain credit from reacting to such events.

The explanations focus on both contextual factors, such as institutional and government characteristics, and individual factors, that is, voter characteristics. First, political institutions shape the responsibility governments have for the economy (Powell and Whitten 1993; Anderson 2000; Duch and Stevenson 2008). Political institutions create a responsibility structure and provide signals to voters on the responsibility of governments for economic outcomes. Nadeau et al. (2002), for example, show that voters punish the prime minister's party less for an adverse economy if it is part of a government coalition. Similarly, the extent to which the national economy is integrated into a global economy makes it unclear for voters how responsible national governments are for economic outcomes (Duch and Stevenson 2010). Hellwig (2008) shows that evaluations of economic performance matter less for voters as a result of globalization (see also Hellwig and Samuels 2007). In other words, the more integrated an economy is in global markets, the smaller is the impact of the economy on government evaluations.

Second, for the individual-level factors, a growing body of literature shows that voters' assessment of the economy is driven by politically motivated reasoning (Evans and Andersen 2006; Stanig 2013; Bisgaard 2015). Voters engage in selective attribution of responsibility for economic outcomes, and partisans who support the government are less critical of the government's economic performance than partisans who do not support the incumbent party (Boef and Kellstedt 2004; Enns et al. 2012). Consequently, government supporters will not punish the government for economic downturns but turn to alternative explanations, for example, how a downturn is generated by an economic slump in export markets and not by the government.

In addition, political sophistication can condition the relevance of the economy (de Vries and Giger 2014; Alt et al. 2016). The more politically sophisticated a voter is, the less likely it is that he or she will punish the government for the state of the economy (Gomez and Wilson 2001). The argument is that, as the economy is affected by a variety of factors beyond the control of the government, only the less politically sophisticated voters will make the government completely responsible for the state of the national economy. However, there are multiple potential pathways in which political sophistication might play a role. Political sophisticates, for example, can be impacted by economic changes in distinct ways through their pocketbook, thus resulting in a potential impact on the national economy.

The above-mentioned studies suggest that the economy, to a varying extent, matters for government support and show that the relevance of the economy is conditional upon contextual and individual factors. Consequently, in line with the core of the economic voting literature on performance judgment, we argue that governments are able to mitigate the relevance of the economy during economic downturns. In addition, in the next section, we outline how governments might be able to increase their level of support in the electorate during economic downturns.

\section{Government support in the wake of a bailout}

Most studies on voter reactions to immediate hardship stem primarily from noneconomic policy areas. These studies have examined government's policy response to exogenous events in situations where the government is not held directly responsible (Healy and Malhotra 2009; 2013). Bechtel and Hainmueller (2011) use the 2002 Elbe flooding in Germany to examine the effects of the incumbent's policy response and find that the German government increased its voter support because of its policy initiatives. Similarly, Gasper and Reeves (2011) find that, although voters punish incumbents for severe weather damage, they are ready to appreciate their action that alleviated the consequences of extreme weather. Exploiting climatic shocks and economic shocks in the Caribbean, Remmer 
(2014) finds, voters reward governments for good performance of the local economy, but Remmer finds no significant correlation between economic shocks and assessments of the government.

The financial crisis made it difficult for voters to blame the government for the economic climate of the national country (Helleiner 2011; Anderson and Hecht 2012), and governments use economic policies in the wake of financial crises to ease future crises (McGrath 2017). Previous research finds that when voters are faced with inadequate status quo, for example, a financial crisis, voters credit governments for taking any sort of action in order to address the situation (Egan 2014). Shehata and Falasca (2014) find that the financial crisis made citizens' attributions of responsibility for the economy more important in their government evaluations.

Following recent studies on economic policy and policy preferences in response to negative events, we expect that governments have opportunities to not only reduce the severity of punishment for economic downturns, but also to increase its level of popularity (Gasper and Reeves 2011; McGrath 2017; Ashworth et al. 2018). We propose that voters do not solely rely on information on the state of the economy but react to actual government policy responses, and while the former is often rightfully used as a heuristic for the performance of governments, voters can rely on the policy actions of the government in response to a clearly inadequate status quo (Egan 2014).

In sum, by linking the economic voting literature to recent studies on public evaluations in the wake of exogenous events, we have reasons to believe that voters are not blind in their retrospective evaluations of the government. On the contrary, they are able to credit the government for its policy to ameliorate the effects of a prominent economic crisis.

We focus on economic shocks caused by financial events in the form of banking crises (Rosas 2006; 2009; Grossman and Woll 2014). Banking crises are exogenous, highly visible, and unambiguously negative economic events that signal a crisis in a country's economy (Holbrook et al. 2012; Crespo-Tenorio et al. 2014). Banking crises are unexpected, provide a discontinuity in the state of the economy, and pose a threat to macroeconomic stability due to increased financial and economic insecurity (McGrath 2017). In effect, banking crises are likely to cause voters to reconsider their beliefs about the state of the economy, which makes such crises well suited for a study of the public response to government policies.

Specifically, a banking crisis is ideal to test whether voters credit the government for a strong policy response or punish the government unconditionally because of a worsened economy. Previous research finds that an economic crisis is the best case where economic perceptions will exogenously influence government support (Chzhen et al. 2014), and voters have clear expectations that the government should react by proposing and enacting alleviating policies (Egan 2014; Malhotra and Margalit 2014). Thus, when the government provides a policy response in the form of a government bailout, we are able to examine the extent to which voters are able and willing to credit the government for a response to the crisis.

In sum, focusing on a government bailout makes it possible to study a brief period compared to other studies in the economic domain, limiting the influence of alternative explanations for government evaluations, such as the role of political institutions and government characteristics introduced above. The empirical strategy outlined in the next section allows us to examine the extent to which governments are able to increase their level of support with a bailout as the response to a financial crisis.

\section{Empirical strategy}

For our research, we rely on the outbreak of the financial crisis in the Netherlands, taking advantage of a unique opportunity to examine how the public reacts when experiencing a government bailout. On Friday September 26, 2008, the financial crisis took full effect in the Netherlands when Fortis N.V. lost almost 21\%. of its value on the Amsterdam Stock Exchange. The Dutch government intervened with a bailout on September 28. The outbreak of this particular banking crisis, 


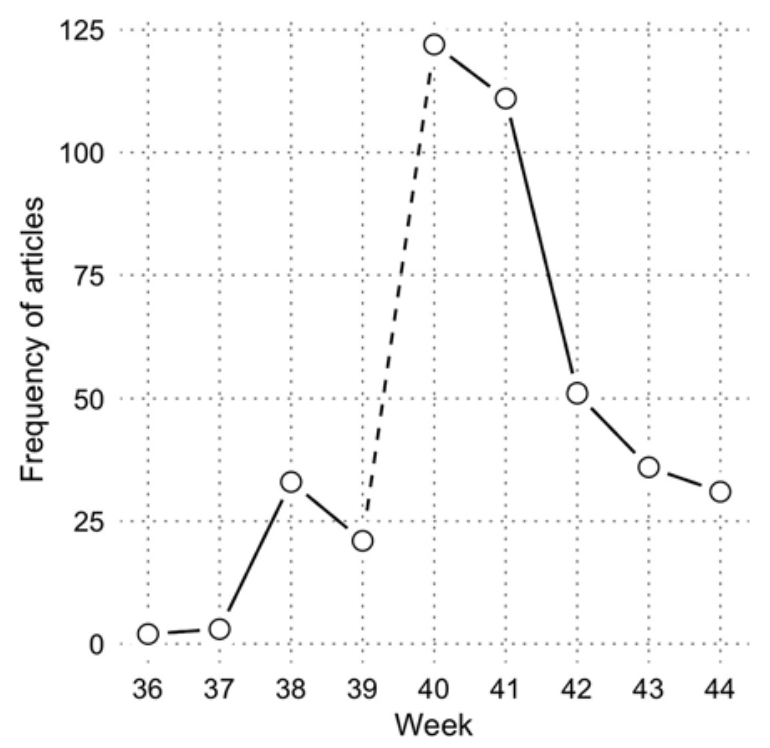

Figure 1. Press coverage of Fortis and crisis.

Note: The dashed line indicates the week of the outbreak of the financial crisis. The points show the frequency of articles in five newspapers, Algemeen Dagblad, NRC Handelsblad, De Telegraaf, Trouw, and de Volkskrant, mentioning both Fortis and crisis in the LexisNexis database. For more information on the case and the qualitative content analysis, see Online Appendix A.

followed by the bailout, provides an ideal situation to examine whether government evaluations are causally related to economic evaluations.

Fortis was the first major European bank to fail in mainland Europe as a result of the financial crisis (Fassin and Gosselin 2011: 169; Kickert 2012). Fortis had its home base in the Benelux countries and was one of the top five financial institutions in the EU. The status quo without a bailout would have had catastrophic consequences for the economy. The governments of Belgium, the Netherlands, and Luxembourg invested 11.2 billion euros in the failing Fortis Bank.

To shed light on the extent to which the crisis was salient, we analyzed news stories in the major Dutch newspapers, Algemeen Dagblad, NRC Handelsblad, De Telegraaf, Trouw, and de Volkskrant. Importantly, there was a substantial increase in the coverage mentioning both the crisis and Fortis in the wake of the crisis. Figure 1 shows the number of articles mentioning 'crisis' and 'Fortis'.

The banking crisis happened in the wake of the collapse of Lehman Brothers in the US, stressing the importance of substantiating that the banking crisis in the Netherlands was not anticipated. Going through the coverage of the financial crisis in the Netherlands from the period surrounding the banking crisis with Fortis, we found no evidence that the banking crisis was expected. On the contrary, we found statements in the media prior to the crisis that no Dutch bank would experience a banking crisis. In Online Appendix A, we provide a study of the coverage of the financial crisis and outline the context for the financial crisis in the Netherlands and the Dutch government's policy response to bail out Fortis N.V.

To examine how citizens reacted to the banking crisis, we rely on three high-quality data sources: the European Social Survey (ESS), a cross-national survey conducted in 2008 (European Social Survey Round 4 Data 2008), the Longitudinal Internet Studies for the Social Sciences (LISS), a representative sample of Dutch individuals who participate in monthly Internet surveys (Scherpenzeel 2011), and the Eurobarometer, a repeated cross-sectional survey. Eurobarometer does not include measures directly comparable to the ESS and LISS. Accordingly, we use it primarily as a conceptual replication of the main trends found in the ESS and LISS.

The fourth round of the ESS was in the field in the Netherlands from September 9, 2008, to June 27,2009 , and the majority of the respondents were interviewed in $2008 ; 1,778$ respondents 


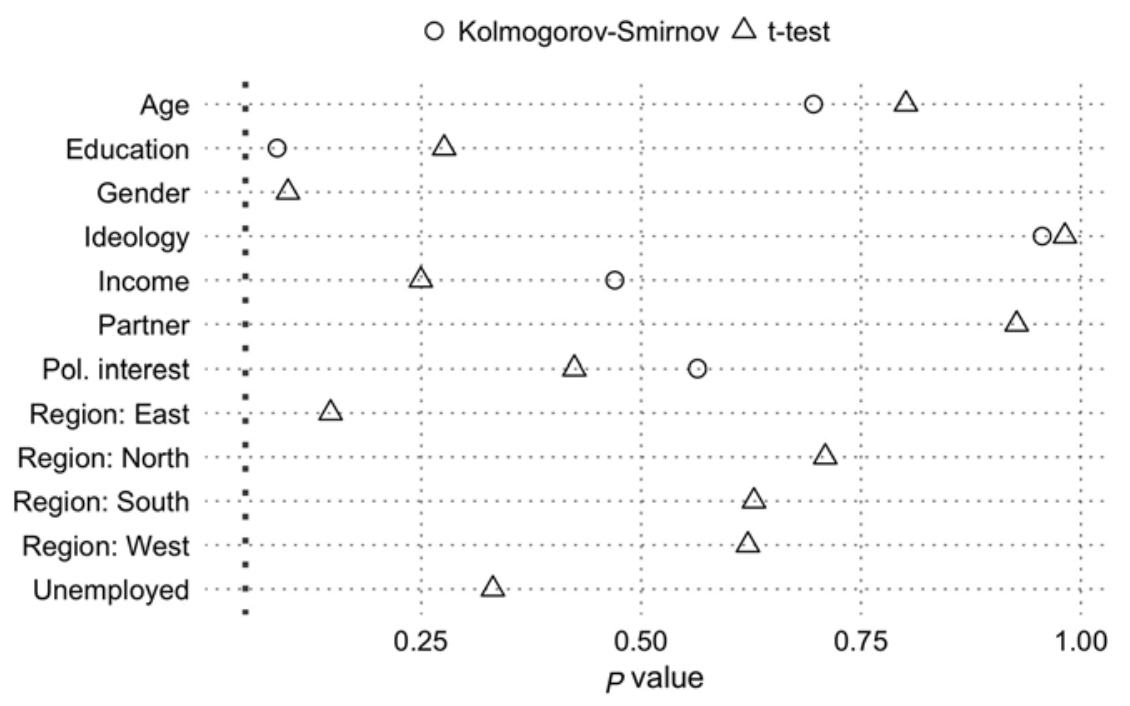

Figure 2. Balance tests on covariates, ESS.

Note: Two-sided $P$-values for differences in socio-demographic and political covariates. Circles denote Kolmogorov-Smirnov tests (for continuous variables). Triangles denote t-tests (for all variables). The dashed line indicates the 0.05 threshold.

participated, and the response rate was $49.8 \%$. To limit the potential relevance of other events, we focus on the respondents interviewed in the months surrounding the event, that is, in September, October, and November. Importantly, we are not aiming for a sample of respondents representative of the general population, but respondents comparable to each other with the exception of the exposure to the government bailout. A total of 262 respondents were interviewed before September 26, 2008. The respondents interviewed before the crisis broke out constitute the baseline group who is unaffected by the salient banking crisis in the financial sector and government bailout that would occur only a couple of days after September 26.

The logic behind the use of the ESS data is that differences in voters' perceptions of government performance are attributable to the government bailout. In other words, the first group (control) consists of all the respondents interviewed prior to the government's policy response, and the second group (bailout) consists of the respondents interviewed after the bailout, that is, after September 28 and throughout October and November. In sum, by limiting the time span to the period when the salient crisis happened, we can generate comparable control and treatment groups to estimate the causal impact of the crisis (for a similar empirical strategy to study the impact of economic events and policies, see Schaffner and Roche 2017 and Larsen 2018).

The validity of the findings rests on the assumption of nonconfounding, that is, that the respondents in the two groups are similar except on exposure to the crisis. We examine the balance between the control and treatment group by testing for differences on a set of relevant covariates. The assumption is that if the two groups are similar on observable covariates, they are similar on unobservable covariates as well.

Figure 2 shows $P$-values from univariate tests for differences between the two groups on gender, age, education, income, partner status, unemployment, political interest, left-right ideology, and NUTS-1 regional divisions (see Online Appendix B and C for question wordings and descriptive statistics). The two tests are t-tests for all covariates and the bootstrap Kolmogorov-Smirnov test for the continuous covariates. The last test considers distributional features and can therefore be seen as a more demanding test compared to the t-test (Ho et al. 2007). The dashed grey line highlights a $P$-value of 0.05 . The figure shows that there are no substantial or significant differences between the two groups on the observable controls. We are thus confident that any differences between the groups can be attributed to the bailout in question. 
Table 1. Overview of data sources

\begin{tabular}{|c|c|c|c|}
\hline & ESS & LISS & Eurobarometer \\
\hline Type & Cross-sectional & Panel & Cross-sectional \\
\hline Comparison & Between subjects & Within subjects & Between subjects \\
\hline Groups & $\begin{array}{l}\text { Pre: Sep 1-Sep 26, } 2008 \\
\text { Post: Sep 28-Nov 31, } 2008\end{array}$ & $\begin{array}{l}\text { Pre: Dec, } 2007 \\
\text { Post: Dec, } 2008\end{array}$ & $\begin{array}{l}\text { Pre: Apr, } 2008 \\
\text { Post: Oct } 2008\end{array}$ \\
\hline Outcome & & & \\
\hline Economic evaluation & $\begin{array}{l}\text { Pre: Mean: } 5.89 \\
\text { S.d.: } 1.84 \\
\text { Post: Mean: } 5.55 \\
\text { S.d.: } 1.88\end{array}$ & $\begin{array}{l}\text { Pre: Mean: } 6.22 \\
\text { S.d.: } 1.49 \\
\text { Post: Mean: } 5.47 \\
\text { S.d.: } 1.66\end{array}$ & $\begin{array}{l}\text { Pre: Mean: } 0.62 \\
\text { S.d.: } 0.65 \\
\text { Post: Mean: } 0.42 \\
\text { S.d.: } 0.66\end{array}$ \\
\hline Government evaluation & $\begin{array}{l}\text { Pre: Mean: } 5.35 \\
\text { S.d.: } 1.94 \\
\text { Post: Mean: } 5.62 \\
\text { S.d.: } 1.77\end{array}$ & $\begin{array}{l}\text { Pre: Mean: } 5.24 \\
\text { S.d.: } 1.81 \\
\text { Post: Mean: } 5.63 \\
\text { S.d.: } 1.77\end{array}$ & $\begin{array}{l}\text { Pre: Mean: } 0.51 \\
\text { S.d: } 0.50 \\
\text { Post: Mean: } 0.69 \\
\text { S.d.: } 0.46\end{array}$ \\
\hline $\mathrm{N}$ & 1039 & 4558 & 2006 \\
\hline
\end{tabular}

Note: For additional information on the data sources, see Online Appendix A, B and C.

The empirical strategy enables us to estimate the causal impact of the bailout. However, it is a between subjects design with different subjects interviewed before and after the outbreak of the crisis. Although we can ensure that there is balance on the observable covariates, we cannot ensure that the groups are similar on unobservable characteristics. To address this limitation, we utilize panel data from the first two waves on political attitudes of the LISS panel, which allow us to draw within-person comparisons. The first wave is from December, 2007, and the second wave is from December, 2008. Here, we focus on the respondents who answered the questions of interest in both waves.

For our primary outcomes, we use two items included in both datasets concerning satisfaction with the economy and with the national government (for question wordings, see Online Appendix B). All items are measured on an 11-point scale. To further examine whether government supporters reacted in a different manner to the crisis compared to opposition supporters, we used information in ESS on recalled vote choice from the national election in 2006, that is, whether the respondent voted for a government party (Christian Democratic Party, Labour Party, or the Christian Union), as ESS does not contain a question on vote intention. From the LISS data, we used information about vote intention in wave 1 .

Finally, the two data sources are either not necessarily nationally representative around the event (a limitation of the ESS data) or with a baseline collected almost a year before the event in question (a limitation of the LISS data). To accommodate this, we rely on two representative surveys from Eurobarometer collected in April and October, 2008. Eurobarometer did not include similar measures of economic and government evaluations, but asked about expectations for the economic situation and trust in the national government. We use these two measures as a conceptual replication of the findings from the ESS and LISS datasets.

Table 1 summarizes the differences between the two designs and data sources as well as means and standard deviations for the key variables.

In the sections that follow, we carry out the analyses in five steps. First, we study how the public reacted to the crisis on their evaluations of the economy and the government. Second, we disaggregate the findings and examine responses conditional upon individual-level differences in income. Third, we examine how government and opposition supporters reacted to the crisis. Fourth, we conduct a series of placebo tests to substantiate the findings. Fifth, we provide a replication of the results of the direct impact of the bailout on people's evaluations.

\section{Results: direct effects}

To know how the public reacted to the crisis, we conducted simple statistical tests on the mean differences between the pre- and postmeasures on the ESS and LISS data. To recall, if voters are 


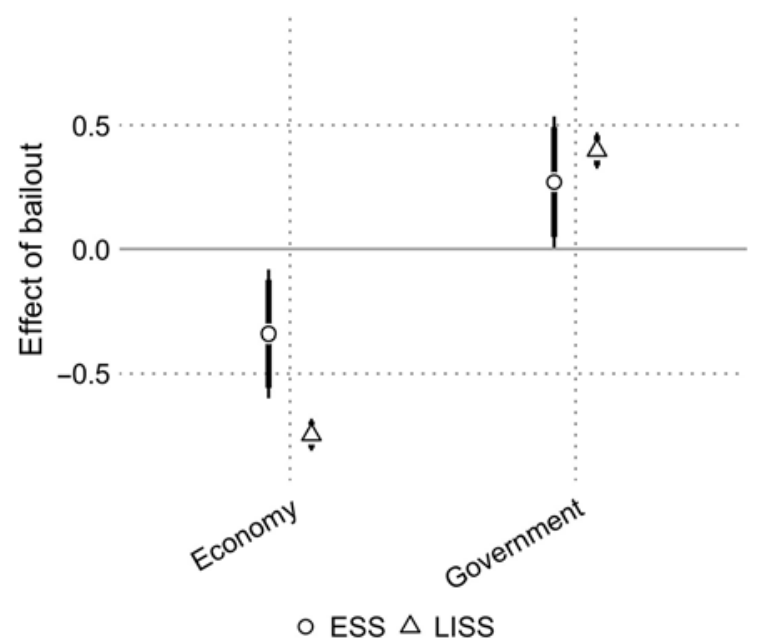

Figure 3. Evaluations of the economy and the government.

Note: Mean differences in economic and government evaluations as a result of the government bailout. The thick lines indicate $90 \%$ confidence intervals; the thin lines indicate $95 \%$ confidence intervals. The results from LISS are fixed-effects regression coefficients. For numerical estimates as well as regression models, see Online Appendix D.

blindly retrospective, we should expect that economic evaluations and government evaluations follow each other closely in response to a salient government bailout. Figure 3 shows the effect of the government bailout on economic evaluations and government evaluations.

The economic evaluations are - as expected - more negative as a result of the outbreak of the financial crisis. Citizens' satisfaction with the economy decreases during a macroeconomic crisis. This is in line with previous studies that focused on how exogenous shocks affect voters' assessment of the economy. The difference between the two groups in the ESS data is -0.34 and is statistically significant $(P<0.05$, two-sided test). Note, of course, that the short-term impact of the global financial crisis may be underestimated since respondents in the baseline group are interviewed after the collapse of Lehman Brothers in the US. The difference in the LISS data is -0.74 and statistically significant $(P<0.01$, two-sided test). Both estimates suggest that the banking crisis had a negative impact on citizens' evaluation of the economy. This allows us to examine whether this negative change led to a similar negative change in citizens' level of satisfaction with the government.

Turning to government evaluations, we find a positive response. In the wake of the bailout, respondents are more satisfied with the national government. The difference between the two groups in the ESS data is 0.27 and statistically significant $(P<0.05$, two-sided test). The difference between the pre- and postmeasure in the LISS data is 0.41 and is also significant $(P<0.01$, two-sided test). This shows that a change in voters' assessment of the economy in the wake of a crisis does not have a similar causal effect on their satisfaction with the government. Hence, in the domain of exogenous economic crises, governments are not only able to mitigate the punishment from the voters in times of crisis, but also increase their level of support in times of crisis.

These findings are in line with our expectation that voters are able to evaluate the government on the basis of its response to a crisis, even when the economy is unambiguously worse off.

\section{Results: did income moderate the effects?}

To study if economic characteristics shaped how people updated their evaluations of the economy of the government, we examined the heterogeneous responses to the government bailout based on income. In Table 2, we show that income accounts for changes in economic evaluations after the bailout: for LISS, the greater the income, the greater the drop in economic evaluations from 2007 
Table 2. Heterogeneous response to bailout, income, OLS regression

\begin{tabular}{|c|c|c|c|c|}
\hline & ESS & ESS & LISS & LISS \\
\hline Bailout & $\begin{array}{c}\text { Economy } \\
0.518 \\
(0.331)\end{array}$ & $\begin{array}{c}\text { Government } \\
0.628^{\star} \\
(0.322)\end{array}$ & Economy & Government \\
\hline Income & $\begin{array}{c}0.187^{\star \star \star} \\
(0.044)\end{array}$ & $\begin{array}{l}0.103^{\star \star} \\
(0.043)\end{array}$ & $\begin{array}{c}-0.034^{\star} \\
(0.019)\end{array}$ & $\begin{array}{c}0.027 \\
(0.018)\end{array}$ \\
\hline Bailout $\times$ Income & $\begin{array}{c}-0.140^{\star \star \star *} \\
(0.051)\end{array}$ & $\begin{array}{l}-0.052 \\
(0.050)\end{array}$ & & \\
\hline Constant & $\begin{array}{c}4.756^{\star \star \star} \\
(0.284)\end{array}$ & $\begin{array}{c}4.699^{\star \star \star} \\
(0.276)\end{array}$ & $\begin{array}{c}-0.638^{\star \star \star} \\
(0.077)\end{array}$ & $\begin{array}{c}0.303^{\star \star \star} \\
(0.072)\end{array}$ \\
\hline Observations & 922 & 926 & 2,731 & 2,731 \\
\hline Adjusted $\mathrm{R}^{2}$ & 0.023 & 0.014 & 0.001 & 0.001 \\
\hline
\end{tabular}

Note: Unstandardized regression coefficients with standard errors in parentheses. For LISS, the outcome variables indicate changes from 2007 to 2008. For robustness tests of the interaction in ESS, see Online Appendix E.

${ }^{\star} P<0.1,{ }^{\star \star} P<0.05,{ }^{* \star *} P<0.01$
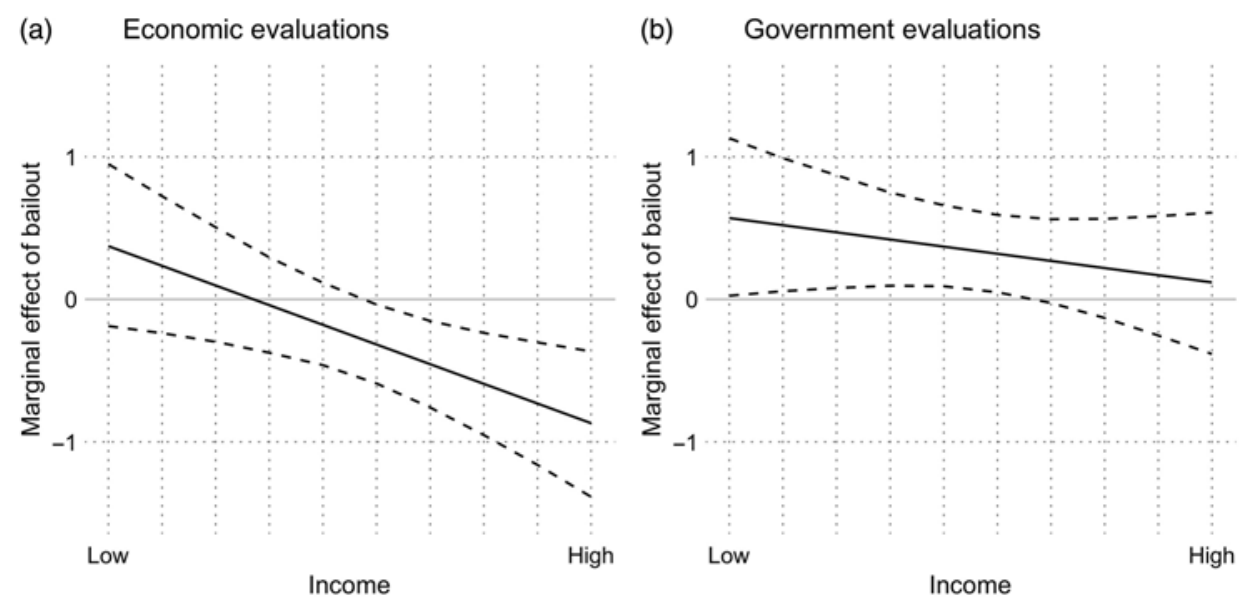

Figure 4. Marginal effect of government bailout on economic evaluations (a) and government evaluations (b). Note: The effect of government bailout on economic evaluations and government evaluations conditional upon income. The dashed lines indicate $95 \%$ confidence intervals. For robustness tests, see Online Appendix E.

to 2008; for ESS, the interaction term is negative and statistically significant. Figure 4 shows the marginal effect on economic evaluations and government evaluations.

Table 2 further shows that the positive change in government evaluations was stable across the income distribution. This means that the public did not respond to the evaluation of the government in a similar way as it responded to the economy. In sum, though some people are more likely to react to negative changes in the economy, people are - on average - ready to credit the government unconditional upon their personal economic situation.

\section{Results: did partisanship moderate the effects?}

Next, people might be biased in their assessment of economic events and react to the crisis in a partisan manner. The data provided in Table 3 help us find whether voters who supported the government reacted differently to the state of the economy and the government.

We do not find any evidence that citizens are biased in their assessment of the economy on the basis of their identification with a government party. This speaks to the nature of the financial crisis 
Table 3 Heterogeneous response to bailout, partisanship, OLS regression

\begin{tabular}{lcccc}
\hline & ESS & ESS & LISS & LISS \\
\hline & Economy & Government & Economy & Government \\
Bailout & -0.246 & $0.455^{\star \star}$ & & \\
Government supporter & $(0.217)$ & $(0.209)$ & 0.007 & $-0.199^{\star \star \star}$ \\
Bailout $\times$ Supporter & 0.296 & $\left(0.844^{\star \star \star}\right.$ & $(0.061)$ & $(0.056)$ \\
Constant & $(0.251)$ & -0.243 & & \\
& -0.066 & $(0.278)$ & $-0.743^{\star \star \star}$ & $(0.037)$ \\
Observations & $(0.289)$ & $4.912^{\star \star \star}$ & 3,196 & $(0.034)$ \\
Adjusted $\mathrm{R}^{2}$ & $5.736^{\star \star \star}$ & $(0.183)$ & -0.0003 & 3,196 \\
\hline
\end{tabular}

Note: Unstandardized regression coefficients with standard errors in parentheses. For LISS, the outcome variables indicate changes from 2007 to 2008 .

${ }^{\star} P<0.1,{ }^{\star \star} P<0.05,{ }^{\star \star \star} P<0.01$

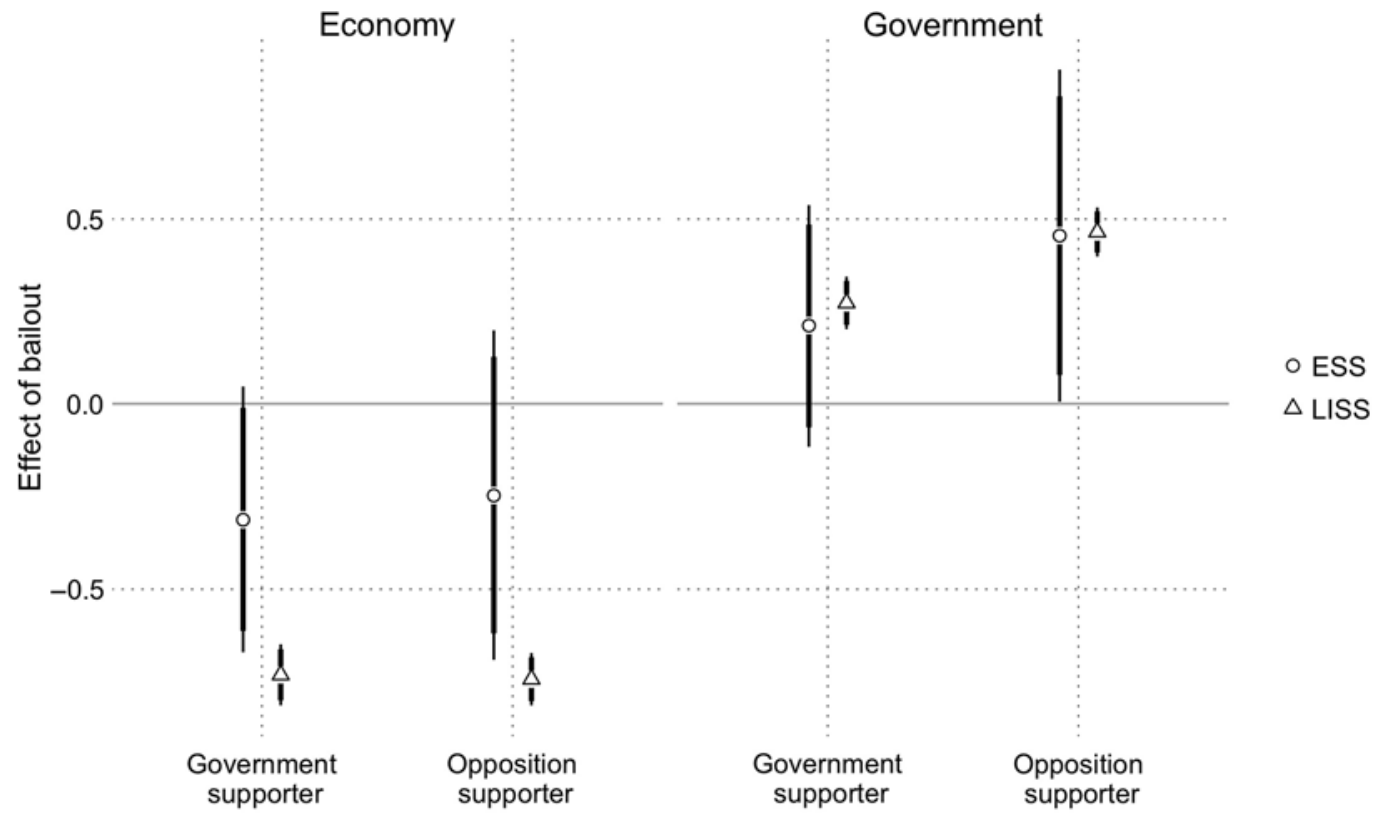

Figure 5. Evaluations and partisanship.

Note: The effect on evaluations conditional upon partisanship. The effects are mean differences in economic and government evaluations as a result of the government bailout. The thick lines indicate $90 \%$ confidence intervals and the thin lines indicate $95 \%$ confidence intervals. The results from LISS are fixed-effects regression coefficients.

that unambiguously worsened the economy, making it difficult for government as well as opposition supporters to disagree on the fact that the economy is worse off (Bisgaard 2015). We find no empirical support that voters are biased in their assessments of the government's response to the crisis. If anything, we find a greater change in satisfaction with the government among opposition voters.

Figure 5 illustrates the effect of the crisis on government evaluations stratified on government support. This effect is larger in the LISS, and the difference between the two groups is not statistically significant in the ESS. In short, the effects provide no support for a biased response to the crisis and the government, but findings in line with a ceiling-effect interpretation, since voters who are already supportive of the government are more likely to perceive the government in a 


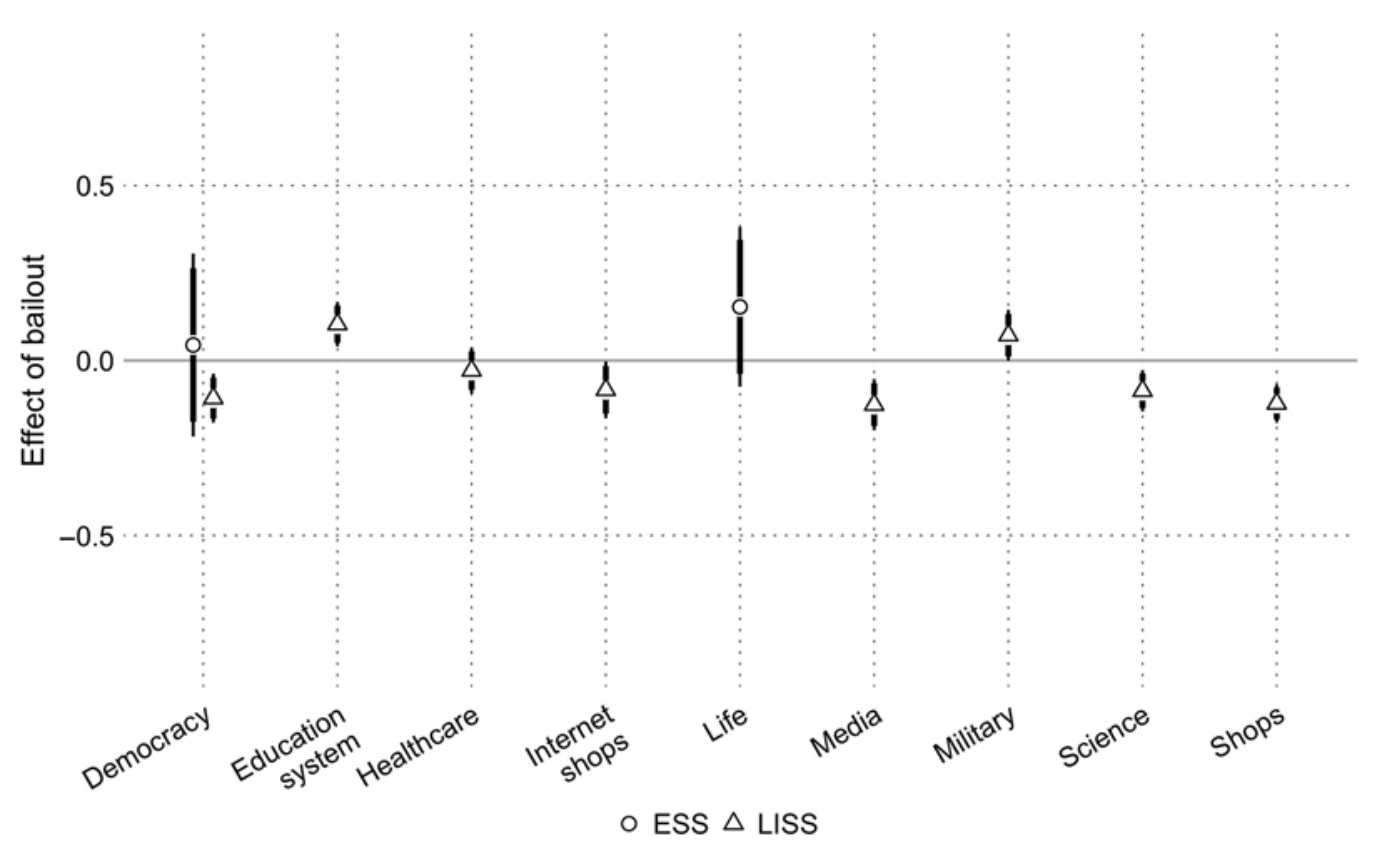

Figure 6. Placebo tests with other satisfaction measures.

Note: Mean differences in satisfaction measures in the ESS and LISS as a result of the government bailout. The thick lines indicate $90 \%$ confidence intervals and the thin lines indicate $95 \%$ confidence intervals.

positive light. This finding suggests that nonsupporters do not unconditionally rely on partisan motivations to evaluate government performance, when the government implements a strong policy response to the crisis.

The results from the two data sources show that voters are willing to give the incumbent government their support as a reward for its crisis response. In other words, and in contrast to arguments about how voters react to negative events in a negative manner, the results show the positive prospects for a government to increase its support during times of economic hardship.

\section{Results: placebo tests with satisfaction measures}

To ensure that the differences are not explained by factors unrelated to specific economic and political trends, we conducted a series of placebo tests with other satisfaction measures. Specifically, we look at nine different satisfaction measures: democracy, education system, healthcare, internet café, life, media, military, science, and shops. The satisfaction with democracy measure was available in both the ESS and LISS. Previous research finds no evidence that the economic crisis had direct effects on satisfaction with democracy (Cordero and Simón 2016). Accordingly, we believe this is a sufficient test to substantiate whether the differences reported can potentially be attributed to other factors.

Figure 6 shows the estimated effects using the same approach for estimating the effects on economic evaluations and government evaluations. We find no systematic evidence for a difference that can account for the main effects reported. For satisfaction with democracy, we find a positive and statistically insignificant change in the ESS, and a minor negative change in the LISS sample. Hence, the systematic and consistent effects across the ESS and LISS data reported above are likely to be attributed to general satisfaction trends.

Noteworthy, some of the differences in the LISS data are statistically significant. However, these differences are substantially smaller than the differences for economic evaluations and 


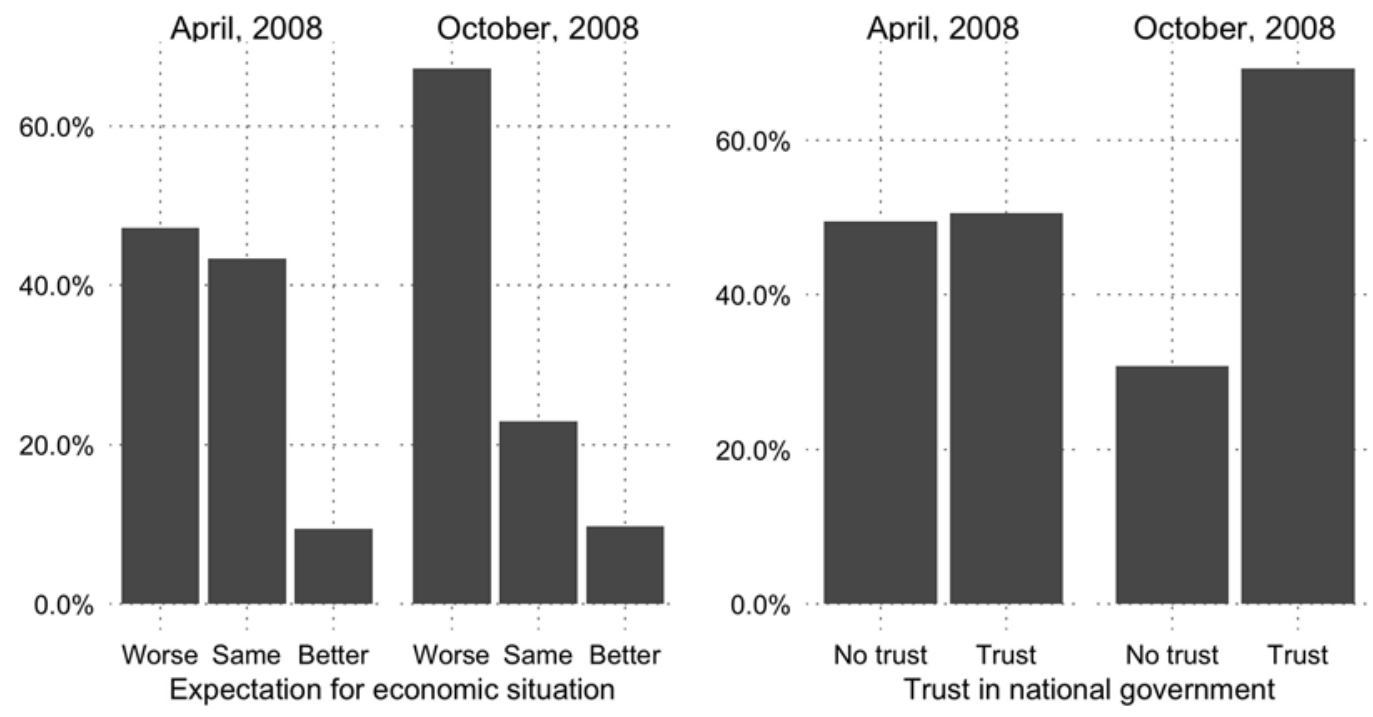

Figure 7. Changes in economic and government evaluations, Eurobarometer.

Note: Distribution of economic and government evaluations before (April 2008) and after (October 2008) the government bailout.

government evaluations, and there are no systematic patterns in the differences that could explain the key findings on economic evaluations and government evaluations. We are thus confident that the systematic patterns can be attributed to the government bailout and not to specific measurement characteristics.

\section{Results: replication with Eurobarometer}

The two datasets used have certain limitations, namely that they favor either the internal validity by comparing respondents just before and after the bailout or the panel data component of the data. Using additional representative survey data, Figure 7 presents evidence on how the public perceived the economy and the government in April, a few months prior to the outbreak of the financial crisis, and in October, days after the crisis.

For the first panel, we see that people's expectations for the economic situation are getting substantially worse from April to October. While using a different measure, this replicates the finding from ESS and LISS, that is, that people perceive the economy significantly worse after the outbreak of the crisis. For the second panel, we look at whether people tend to trust the national government or not. We see that there is a substantial change in the perspective of the Dutch public from April to October, where people depict greater levels of trust in the national government after the bailout.

\section{Discussion and concluding remarks}

We have used the context of the outbreak of the financial crisis in the Netherlands to address whether and how voters respond to a salient government bailout. The theoretical puzzle is whether voters punish the government when they perceive the economy as worsening or whether democratic governments by deliberate policy intervention during a salient economic crisis can affect citizens' assessments of the government. The findings show that taking policy responses into account promotes our understanding of how and when voters react to changes in the economic climate. 
The primary methodological challenge is to disentangle the issue of endogeneity and empirically examine whether voters are in fact able to credit the government for their response to salient economic downturns. Specifically, we often lack credible counterfactuals with exogenous variation in the exposure to economic events. Most studies rely on data collected during or just after elections, making it difficult to isolate the causal effects of events taking place years prior to the election.

Utilizing between and within subjects measures of government evaluations, we provide strong and consistent evidence that satisfaction levels with the government did not decrease due to the outbreak of the financial crisis in the Netherlands, a crisis that was one of the key events in the history of the Dutch economy (Fassin and Gosselin 2011). On the contrary, satisfaction with the government increased in the wake of a salient government bailout. Changes in citizens' level of satisfaction with the economy do not result in an identical and causal change in their level of satisfaction with the government. Hence, voters seem willing to reward governments for taking action in the context of an unambiguous economic crisis. This speaks to the relevance of policies in order to understand public opinion (cf. Larsen 2019).

The results are of importance to our understanding of the ability of the public to hold governments accountable. Voters' evaluation of government performance is a crucial aspect of democratic accountability (Key 1966; Healy and Malhotra 2013), and voters' ability to evaluate the government in the light of its past performance incentivizes incumbents to pursue policies addressing economic crises. The results presented here are important news for democratic accountability: voters do not necessarily become less satisfied with the government due to an increased level of dissatisfaction with the economy. They are able to give elected governments a chance to show that they are capable of handling crises that they did not, at least directly, produce. Furthermore, in the present case, the results suggest that voters do not differ in their willingness to credit the government or are politically biased in their reaction to the government's behavior when the government provides a salient response to a change in the economy. These findings are consistent with recent evidence of voters not being myopic in their response to economic information (Healy et al. 2017).

This contribution is not to deny the relevance of existing explanations of how voters react to economic changes. On the contrary, it is to argue that future research can benefit from integrating government's policy responses into the theoretical framework. In order to disentangle how the public evaluates the government in an adverse economy, as citizens in the Western democracies had to after the outbreak of the global financial and economic crisis, we cannot only expect that voters unconditionally punish the government for a bad economy or respond in a strictly partisan manner.

The three data sources used in this setting add to the validity of our findings, but there are limitations that need to be addressed. The crisis in the Netherlands and the unique data sources allow us to draw strong inferences about the impact of the crisis in this context, but further research is needed in order to make generalizable claims about the external validity. The scope of this article is not to present an explanation for how voters always respond to economic changes, but to show that, at least under some circumstances, people are not blindly retrospective. Thus, although the strong design allows us to examine voters' response to a government policy in an adverse economy, we should be cautious about generalizing the findings to other political systems. That being said, the crisis in the Netherlands was comparable to that faced in a series of other countries across the world, and there is no reason to believe that the patterns demonstrated here will not replicate in other settings.

The evidence presented here is relevant to scholars who study how voters respond to economic downturns, and in particular how governments react to such salient changes. Addressing these questions requires strong empirical strategies that allow researchers to isolate the economy from the specific behavior of the government. This points to an important challenge in the study of bailouts, namely that we do not observe bailouts without any crisis. Specifically, it is difficult 
to separate the impact from a crisis from that of a bailout. Furthermore, the size of the bailout will be related to the magnitude of the crisis, and can even accentuate a crisis. Accordingly, we see relevant avenues for future observational as well as experimental research examining how different policy responses to economic changes affect voters' assessments of the economy and of the government.

Although there is a strong link between the popularity of the government and the propensity to vote for a government party, we do not show that specific government policies in an economic crisis is a guarantee for good reelection prospects. Thus, we are not able to shed light on how voters weigh different policies in relation to other factors that will matter for their vote choice.

To conclude, the findings emphasize the importance of studying the role of government behavior in the domain of economic voting. Events outside the control of incumbents do not go unnoticed by the public, but the relevance for government evaluations is not exogenous to the government's performance. In other words, voters are not always blind and punish the government for an adverse economy but take policies such as bailouts into account.

Author ORCIDs. (D) Erik Larsen 0000-0003-3579-8457

Supplementary material. To view the supplementary material for this article, please visit http://doi.org/10.1017/ S1755773919000092.

Acknowledgment. We thank Martin Bisgaard, Peter Bjerre Mortensen, Gijs Schumacher, Sune Welling Hansen, Zoltán Fazekas, Christian Albrekt Larsen, Jane Gingrich, Paul Marx, participants at the Comparative Politics Seminars at the University of Kent as well as the four reviewers and the editors of the EPSR for comments on earlier versions.

\section{References}

Achen C.H. and L.M. Bartels (2016), Democracy for Realists: Why Elections Do Not Produce Responsive Government. Princeton: Princeton University Press.

Alt J.E., J. Marshall and D.D. Lassen (2016), 'Credible sources and sophisticated voters: when does new information induce economic voting?' Journal of Politics 78: 327-342.

Anderson C.J. (2000), 'Economic voting and political context: a comparative perspective', Electoral Studies 19: 151-170.

Anderson C.J. and J.D. Hecht (2012), 'Voting when the economy goes bad, everyone is in charge, and no one is to blame: the case of the 2009 German election', Electoral Studies 31: 5-19.

Ashworth S., E.B. de Mesquita and A. Friedenberg (2018), 'Learning about voter rationality', American Journal of Political Science 62: 37-54.

Bechtel M.M. and J. Hainmueller (2011), 'How lasting is voter gratitude? an analysis of the short- and long-term electoral returns to beneficial policy', American Journal of Political Science 55: 851-867.

Bisgaard M. (2015), 'Bias will find a way: economic perceptions, attributions of blame, and partisan-motivated reasoning during crisis', Journal of Politics 77: 849-860.

Boef S.D. and P.M. Kellstedt (2004), 'The political (and economic) origins of consumer confidence', American Journal of Political Science 48: 633-649.

Chzhen K., G. Evans and M. Pickup (2014), 'When do economic perceptions matter for party approval?', Political Behavior 36: $291-313$.

Cordero G. and P. Simón (2016), 'Economic crisis and support for democracy in Europe', West European Politics 39: 305-325.

Crespo-Tenorio A.N., N.M. Jensen and G. Rosas (2014), 'Political liabilities: surviving banking crises', Comparative Political Studies 47: 1047-1074.

Dassonneville R. and M.S. Lewis-Beck (2019), 'A changing economic vote in Western Europe? Long-term vs. short-term forces', European Political Science Review 11: 91-108.

de Vries C.E. and N. Giger (2014), 'Holding governments accountable? Individual heterogeneity in performance voting', European Journal of Political Research 53: 345-362.

Duch R.M. and R.T. Stevenson (2008), The Economic Vote: How Political and Economic Institutions Condition Election Results, New York, NY: Cambridge University Press.

Duch R.M. and R.T. Stevenson (2010), 'The global economy, competency, and the economic vote', Journal of Politics 72: $105-123$.

Egan P.J. (2014), “'Do something” politics and double-peaked policy preferences', Journal of Politics 76: 333-349. 
Enns P.K., P.M. Kellstedt and G.E. McAvoy (2012), 'The consequences of partisanship in economic perception', Public Opinion Quarterly 76: 287-310.

European Social Survey Round 4 Data (2008), 'Data file edition 4.3', Norwegian Social Science Data Services, Norway - Data Archive and Distributor of ESS Data for ESS ERIC.

Evans G. and R. Andersen (2006), 'The political conditioning of economic perception', Journal of Politics 68: $194-207$.

Fassin Y. and D. Gosselin (2011), 'The collapse of a European bank in the financial crisis: an analysis from stakeholder and ethical perspectives', Journal of Business Ethics 102: 169-191.

Fiorina M.P. (1978), 'Economic retrospective voting in American national elections: a micro-analysis', American Journal of Political Science 22: 426-443.

Gasper J.T. and A. Reeves (2011), 'Make it rain? Retrospection and the attentive electorate in the context of natural disasters', American Journal of Political Science 55: 340-355.

Gomez B.T. and J.M. Wilson (2001), 'Political sophistication and economic voting in the American electorate: a theory of heterogeneous attribution', American Journal of Political Science 45: 899-914.

Grossman E. and C. Woll (2014), 'Saving the banks: the political economy of bailouts', Comparative Political Studies 47: 574-600.

Healy A. and N. Malhotra (2009), 'Myopic voters and natural disaster policy', American Political Science Review 103: 357-406.

Healy A. and N. Malhotra (2013), 'Retrospective voting reconsidered', Annual Review of Political Science 16: 285-306.

Healy A., M. Persson and E. Snowberg (2017), 'Digging into the pocketbook: evidence on economic voting from income registry data matched to a voter survey', American Political Science Review 111: 771-785.

Helleiner E. (2011), 'Understanding the 2007-2008 global financial crisis: lessons for scholars of international political economy', Annual Review of Political Science 14: 67-87.

Hellwig T. (2008), 'Globalization, policy constraints, and vote choice', Journal of Politics 70: 1128-1141.

Hellwig T. and D. Samuels (2007), 'Voting in open economies: the electoral consequences of globalization', Comparative Political Studies 40: 283-306.

Ho D.E., K. Imai, G. King and E.A. Stuart (2007), 'Matching as nonparametric preprocessing for reducing model dependence in parametric causal inference', Political Analysis 15: 199-236.

Holbrook T.M., C. Clouse and A.C. Weinschenk (2012), 'Bringing the president back in: the collapse of Lehman brothers and the evolution of retrospective voting in the 2008 presidential election', Political Research Quarterly 65: 263-274.

Key V.O. (1966), The Responsible Electorate: Rationality in Presidential Voting, 1936-1960. New York, NY: Vintage Books.

Kickert W. (2012), 'How the Dutch government responded to financial, economic and fiscal crisis', Public Money \& Management 32: 439-443.

Larsen E.G. (2018), 'Welfare retrenchments and government support: evidence from a natural experiment', European Sociological Review 34: 40-51.

Larsen E.G. (2019), 'Policy feedback effects on mass publics: a quantitative review', Policy Studies Journal doi: 10.1111/psj. 12280.

Lewis-Beck M.S. and M. Stegmaier (2000), 'Economic determinants of electoral outcomes', Annual Review of Political Science 3: $183-219$.

Lewis-Beck M.S. and M. Stegmaier (2007), 'Economic models of voting', in R.J. Dalton and H. Klingemann (eds.), The Oxford Handbook of Political Behavior. Oxford, UK: Oxford University Press, 518-537.

Lewis-Beck M.S. and R. Nadeau (2011), 'Economic voting theory: testing new dimensions', Electoral Studies 30: 288-294.

Lindvall J. (2014), 'The electoral consequences of two great crises', European Journal of Political Research 53: 747-765.

Malhotra N. and Y. Margalit (2010), 'Short-term communication effects or longstanding dispositions? The public's response to the financial crisis of 2008', Journal of Politics 72: 852-867.

Malhotra N. and Y. Margalit (2014), 'Expectation setting and retrospective voting', Journal of Politics 76: $1000-1016$.

Margalit Y. (2019), 'Political responses to economic shocks', Annual Review of Political Science 22: 277-295.

McGrath L.F. (2017), 'Insuring against past perils: the politics of post-currency crisis foreign exchange reserve accumulation', Political Science Research and Methods 5: 427-446.

Nadeau R., R.G. Niemi and A. Yoshinaka (2002), 'A cross-national analysis of economic voting: taking account of the political context across time and nations', Electoral Studies 21: 403-423.

Nannestad P. and M. Paldam (1994), 'The VP-function: a survey of the literature on vote and popularity functions after 25 years', Public Choice 79: 213-245.

Powell G.B. and G.D. Whitten (1993), 'A cross-national analysis of economic voting: taking account of the political context', American Journal of Political Science 37: 391-414.

Remmer K.L. (2014), 'Exogenous shocks and democratic accountability: evidence from the Caribbean', Comparative Political Studies 47: 1158-1185.

Rosas G. (2006), 'Bagehot or Bailout? An analysis of government responses to banking crises', American Journal of Political Science 50: 175-191. 
Rosas G. (2009), Curbing Bailouts: Bank Crises and Democratic Accountability in Comparative Perspective. Ann Arbor, MI: University of Michigan Press.

Schaffner B.F. and C. Roche (2017), 'Misinformation and motivated reasoning: responses to economic news in a politicized environment', Public Opinion Quarterly 81: 86-110.

Scherpenzeel A. (2011), 'Data collection in a probability-based internet panel: how the LISS panel was built and how it can be used', Bulletin of Sociological Methodology/Bulletin de Methodologie Sociologique 109: 56-61.

Shehata A. and K. Falasca (2014), 'Priming effects during the financial crisis: accessibility and applicability mechanisms behind government approval', European Political Science Review 6: 597-620.

Stanig P. (2013), 'Political polarization in retrospective economic evaluations during recessions and recoveries', Electoral Studies 32: 729-745.

Teixeira C.P., E. Tsatsanis and A.M. Belchior (2016), 'A 'necessary evil' even during hard times? Public support for political parties in Portugal before and after the bailout (2008 and 2012)', Party Politics 22(6): 719-731.

Tilley J. and S.B. Hobolt (2011), 'Is the government to blame? An experimental test of how partisanship shapes perceptions of performance and responsibility', Journal of Politics 73: 316-330.

van der Brug W., C. van der Eijk and M.N. Franklin (2007). The Economy and the Vote: Economic Conditions and Elections in Fifteen Countries, New York, NY: Cambridge University Press.

Cite this article: Larsen EG, Klemmensen R, and Klitgaard MB (2019). Bailout or bust? Government evaluations in the wake of a bailout. European Political Science Review 11, 231-246. https://doi.org/10.1017/S1755773919000092 